\title{
A "grass-roots" effort for the future
}

\section{The Grazing Lands Conservation Initiative (GLCI) aims to assist land managers in maintaining and improving the productivity and health of America's privately owned grazing land. \\ By Kindra Gordon}

For North Dakota livestock producers seeking advice on rotational grazing strategies, pasture weed control methods, or any other question relating to grazing management, help is just a phone call away.

It's part of a Grazing Management Network the state has set up that allows producers to call on a dozen experienced ranchers and land managers for insight and ideas about grassland management.

Organized by the North Dakota Private Grazing Lands Coalition, the network is just one example of a growing nationwide effort geared toward improving grazing management. Today, nearly 30 states have coalitions similar to the North Dakota group, and each is devoted to providing private landowners with information, guidance and technical assistance on range, pasture and grasslands.

These grass root efforts were born out of a national initiative established over a decade ago known as the Grazing Lands Conservation Initiative (GLCI). The goal of GLCI is to be a resource for private landowners to turn to for advice on how to better manage grazing lands, according to Tim Munns, a Utah cattleman who serves on the national GLCI steering committee.

To that end, GLCI activities across the nation include workshops and ranch tours, newsletters, demonstration sites and trained range specialists all aimed at helping land managers implement sound grazing practices.

"We need a cooperative effort to keep grazing lands healthy," says Munns, who runs a 400 head commercial herd in northern Utah and currently serves as the president of his state cattlemen's association.

"We don't want a government mandate, but private landowners often need and appreciate technical advice in properly managing grazing lands," he adds. It was that very mission that prompted the formation of GLCI back in 1991.

\section{The Need For GLCI}

Up until the mid-80's, the Natural Resources Conservation Service (NRCS) traditionally had provided voluntary, technical assistance on private grazing lands. But, the 1985 and 1990 Farm Bills, redirected the major focus of NRCS to conservation planning and compliance on highly erodible cropland. As a result, personnel trained in conservation planning on grazing land dwindled and only about $2 \%$ of the NRCS budget was devoted to providing technical assistance to private grazing landowners.

With grazing land comprising the largest single land use of all privately-owned land in the U.S. (and constituting nearly one-half of the non-federal land in the country), many ranchers began to express concern regarding the future of private grazing lands. Texas rancher John "Chip" Merrill was among them.

"These lands are the breeding and growing ground for the country's cattle and sheep; they constitute major watersheds, wildlife habitat, and are a source of recreation and open space amenities," Merrill says. Because of that, he and other GLCI supporters advocated that private landowners needed access to

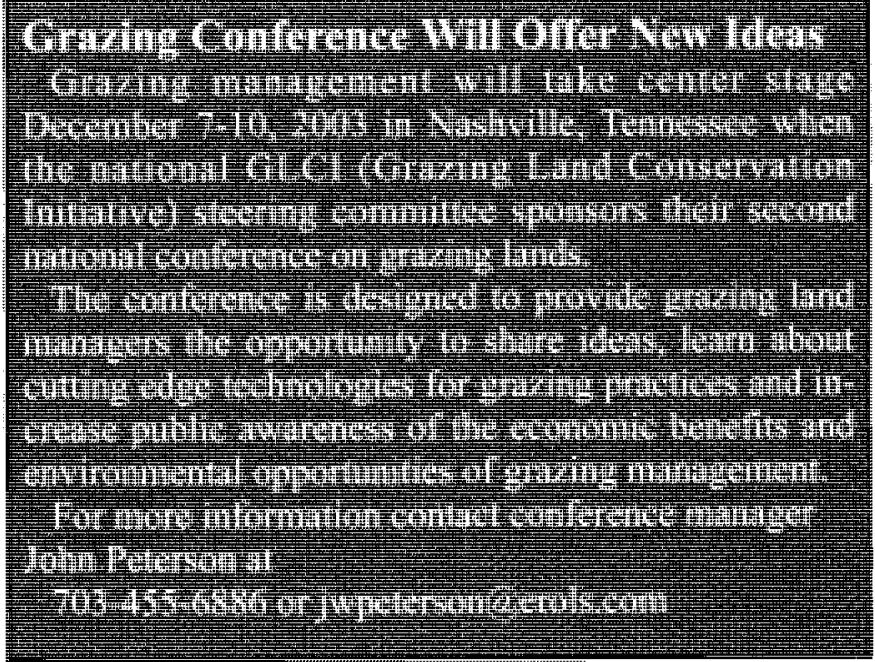


information and technical assistance to ensure the long-term viability of grazing lands.

That's where GLCI and its state affiliates stepped in. In 1991, nine member organizations including the American Farm Bureau Federation, American Forage and Grassland Council, American Sheep Industry, Dairy Industry, National Association of Conservation Districts, National Cattlemen's Beef Association, National Farmers Union, Society for Range Management and the Soil and Water Conservation Society came together to form GLCI on a national level.

Today, representatives from each of the nine member organizations serve on the national GLCI steering committee, and all of them are livestock producers like Merrill and Munns. Their primary aim is to enhance privately owned grazing lands by making voluntary technical assistance - primarily through NRCS personnel - available to the people who manage these lands.

In addition to support from NRCS, the efforts of this national coalition are also carried out through the work of individuals and ag organizations at the local, state, regional and national levels

"The fact that nine organizations have come together for the benefit of one cause - providing voluntary, technical assistance on grazing lands - really dictates the importance of the GLCI effort. GLCI has become one of the strongest forces in support of conservation legislation, and I credit that to the efforts of all nine member organizations," Merrill says.

\section{The Road Ahead}

While GLCI has established its purpose over the last eleven years and experienced some success, Merrill says there is still a long road ahead. In short, he says, "Funding for technical assistance on grazing land is still inadequate."

He outlines GLCI's goals as three-fold:

1) To garner funding to restore NRCS technical assistance,

2) To secure increased research funding for soil, water, plant and wildlife sciences, and

3) To advocate funding for conservation outreach efforts involving Extension agencies and universities.

Merrill says the GLCI steering committee has worked to get these efforts funded through stand- alone legislation or as part of the Farm Bill. They've been successful in that Conservation of Private Grazing Land legislation was lobbied for and passed as part of the 1996 Farm Bill with the intent of providing up to $\$ 60$ million for acceleration of NRCS technical assistance efforts. But the legislation was never funded.

In the 2002 Farm Bill, the Conservation of Private Grazing Land (CPGL) program was again authorized and published in the Federal Register on Nov. 12,2002 . If funded, the CPGL program would allow NRCS conservationists to be better able to assist individuals in understanding the basic ecological principals associated with managing their land and implementing conservation management plans.

"This rule builds our capacity to provide technical assistance to those who own and operate private grazing land," said NRCS Chief Bruce Knight. "This is a voluntary program that address natural resource concerns on private grazing land while enhancing the economic and social stability of grazing land enterprises and the rural communities that depend on them," he adds.

For more on GLCI and state grassland coalitions, visit www.glci.org

Note: North Dakota producer Keith Bartholomay and longtime Idaho rancher Bud Purdy currently represent SRM on the National GLCI Steering Committee. 